\title{
SPEAKING ABILITY THROUGH SHOW AND TELL
}

\author{
Dewi Sri Kuning \\ dewisrikuning@gmail.com \\ Pendidikan Bahasa Inggris \\ Universitas Muhammadiyah Kotabumi
}

\begin{abstract}
Abstrak
Berbicara merupakan salah satu kemampuan yang harus dimiliki oleh siswa dalam belajar bahasa Inggris, karena berbicara digunakan sebagai alat untuk berkomunikasi satu dengan yang lainnya. Pengajaran berbicara untuk anak-anak bukanlah hal yang mudah, karena diperlukan metode yang menyenangkan dan tidak membosankan. Salah satu metode pengajaran berbicara untuk anak-anak adalah Show and Tell. Show and Tell adalah sebuah metode pembelajaran dimana mereka bisa menunjukkan dan menceritakan objek yang ditemuinya dengan berbicara secara langsung. Tujuan dari Show and Tell adalah untuk meningkatkan kemampuan mereka dalam berbicara bahasa Inggris, meningkatkan kepercayaan diri, menimbulkan keberanian, dan berani dalam bersosialisasi dengan orang lain.
\end{abstract}

\section{Kata Kunci : berbicara, show and tell, metode pembelajaran}

\section{Introduction}

Teaching speaking to the young learners is not easy. Teacher has to find out the best method to teach them, so they can get the teacher's point. Halley and Austin (2004:189) state that to be more orally productive, learners would need to be more capable of responding in a relevant and socially appropriate manner to the communication of others. It means that to teach speaking in the classroom, teacher can use a number of verbal strategies to check the students' understanding and get them to speak. They also have the students work in pairs, and the task in the back provides them with something to talk about. Learning English should be fun and natural for children. The language should be first presented through sounds, not written symbols. Children are more sensitive to anything that touches the senses. Meaning should be made perceptible through concrete objects. The idea that teaching should start from what the students already know in order to encourage association processes seems to favor children. Most of the classrooms speaking activities are in the communicative situations. So, an important role for teachers who are aiming to improve 
their student's ability to speak effectively may be to find ways to provide support for learners with various kinds of learning styles so that they can learn in the ways which suit them best. In this case, all students are expected to talk English actively however their mother tongue is not English. By practicing it, they try to negotiate meaning. Therefore, the teacher should support them especially young learners to speak English confidently.

In Indonesian classroom context, teaching speaking is quite challenging for English teachers. This is due to lots of limitation on teachers' part as well as students'. That is why in teaching and learning process, teachers ideally need so many variations of attractive methods of teaching the speaking skills to stimulate students to participate more in learning speaking and improve their ability in speaking. According to many literatures, among numerous teaching speaking methods available, one of the most effective one that can motivate students to speak and to participate to speak in learning process is a method called Show and Tell method.

\section{Discussion}

\section{A. Definition of Show and Tell Methods}

Show and Tell is a method in teaching and learning process by sharing time activity for students. Barletta (2008, as cited in Mortlock 2014) Show and Tell method denotes a practice whereby children are given opportunity to share an oral narrative about an object or experience. The object or experience is usually from their home-life and told orally with their peers and with the teacher's support. Whereas Show and Tell (Walter, 2008) means a school activity for young children in which a child brings an object into the class and talks. Random House Kernerman Webster's College Dictionary (2010) states that Show and Tell is (1) a classroom activity for young children in which each child produces an object and talks about it, or (2) any informative presentation or demonstration.

Raines \& Canady (1990) in Dailey (1997) state that "Show and Tell can provide an opportunity for learners to seek and construct meaningful communication as they make sense of their world and represent their learning through spoken language. Tilaar (2013) Show and Tell method is activity prioritizing the ability to communicate simple. Musfiroh (2011) states that a Show and Tell activity showed something to the audience and explain or describe something. Show and Tell is the process of showing an audience something and telling them about it. Usually, children are allowed to bring something that they live from home and they will explain and share to their friends about something that 
they bring. Norton (1980:59) says that during a show and tell experience, the child talks about an activity or shows an object that he has brought to school. The children voluntarily take turns talking about their object or activity. So, it makes the students relaxed when they are talking each others.

Show and Tell as a technique of learning in which students tell about an object or process that has been or ever experienced. It is conducted in the classroom for speaking skills, especially for elementary school students. In the process, a student will bring something from home and explain to the classmates why they chose the object, from which they get it, and other important information. One of the best aspects of the Show and Tell is the method can be applied to students in all age groups.

From all definitions mentioned above, it can be stated that Show and Tell is an activity done by young children whom they bring an object based on the topic of the learning into the class and talk to the other children to about. It also means any informative or public presentation or demonstration meaning that they show something and want others to know about it.

\section{B. The Purpose of Show and Tell Method}

One strategy to engage students in practicing effective communication skills is to structure a targeted Show and Tell experience. Teaching students how to engage in dialogue through questioning and making connections, and providing students with specific, but open-ended topic suggestions can turn a traditional Show and Tell experience into a language-rich opportunity for English language practice. The purpose of this activity is to train children to speak in front of the classroom and get children sensitive the simple things every day. Suyanto (2005) states that the method Show and Tell are used to uncover abilities, feelings, and the wishes of children. Every day the teacher can ask two or three children to tell you what you want disclosed. When children tell stories, teachers can conduct an assessment on the child. Teachers can continue topic talked about children as learning.

Nathwani (2012) states this technique can be used with almost any example. However, the concept to be explained by the students should be relatively simple and straight forward. The purpose of this exercise is to facilitate the students exploring issues in a creative way. It may be useful for the teacher to know beforehand what the students plan to present. Hubbard (2009) gives other goal in Show and Tell technique to improve speaking skill, socializing skill, problem solving, and analyzing skill of phenomenon. 
It can be concluded that the purpose of Show and Tell method is to train children to speak in front of the classroom and get children sensitive the simple things every day. They can improve their ability in speaking by telling to other friends about something that they have. So, it will make them easy in telling because the something is very familiar with them.

\section{Application of Show and Tell Method}

Learning English as a second language takes much guided practice. One strategy to engage students in practicing effective communication skills is to structure a targeted Show and Tell experience. Teaching students how to engage in dialogue through questioning and making connections, and providing students with specific, but open-ended topic suggestions can turn a traditional Show and Tell experience into a language-rich opportunity for English language practice.

Thornbury (2005) states that the procedure of Show and Tell Method that giving presentations or talks in real life the experience of standing up in front of their mates and speaking for a sustained turn is excellent preparation for real-life speaking. Meanwhile, Shepley, 2010 tells the application in Show and Tell method can be described as follows: students bring an object to tell in the classroom. Then, the teacher asks them to describe. Teacher also gives some related questions and lets the students discuss about the object. After that, the students come forward to present the object that has been brought and analyzed.

Tilaar (2013) states that Show and Tell method can be applied to show something like a new game equipment, birthday gift, food gift from relatives, tableware, or all the objects that are considered new or interesting items for children. According to Musfiroh (2011), there are several different types of Show and Tell that can be applied, which Show and Tell method with personal objects, food, and images and photos.

a. Show and Tell method with personal objects

Students can bring personal objects for use when doing Show and Tell method such as book, pen, ruler, wardrobe, backpack, shoes, and so on.

b. Show and Tell method with food

Food is the thing they need and have a strong range to develop responsibility and independence. When the students show and tell other friends about it, they can talk about the taste, the main ingredient for making food, colors, and so on.

c. Show and Tell method with images and photos

Images and photos are relatively effective to stimulate the ability of manners, responsibility, and 
independence. For children, the ability to be well received through media stories helped with pictures or photographs.

Based on some of the opinions above, the application of the method Show and Tell can use food, drawings or photographs, new game tool, birthday gifts, tableware, children's work, and all the objects that are considered attractive for children.

\section{The Benefits of Show and Tell Method}

Show and Tell as the first opportunity to young children have to stand up in front of a small group and speak. Whether this opportunity starts when they are in kindergarten or once they start primary school, it is a wonderful introduction to public speaking as they are often given the option of speaking about a topic they know well and are interested in. Speaking about something that they love it will make them love it more.

There are many benefits of show and tell for children, but here are a few:

a. Confidence

Practicing public speaking regularly usually means it begins to feel easier as you get older. Children will also become more comfortable contributing in class and asking questions.

b. Awareness and Gratitude
Preparing a show and tell about a holiday or an old family war medal for example, allows them to form an opinion and think about how it makes them feel.

c. Pride and Self Esteem

Researching a topic they are interested in, thinking creatively and expressing their ideas during their talk, allow children to develop a sense of pride which boosts self esteem.

d. Oral Language Skills and Communication

Speaking in front of a group is an effective activity to encourage the use of descriptive language and develops a child's ability to retell stories - in turn leading to improve communication skills which are important throughout their lives.

e. Active Listening Skills

Being part of a show and tell audience is also an important part of learning. The audience learns to sit still and listen closely to someone other than their teacher, and to be respectful. This is something not all children feel comfortable doing but given enough opportunity, will learn that all questions are good questions and nothing bad happens if you ask a question or share your ideas.

f. Relationships 
Show and tell can also act as an ice breaker and help children connect with their peers in new ways. For example, during a show and tell children may learn new things about each other and may chat at break time if they have discovered they have been to the same place on holiday or played the same sport.

Laurie Patsalides in Ningsih (2014) state that the benefits Show and Tell the method to develop some aspects. They are: children learn to talk and listen, become listeners and introduce themselves, make inquiries based on questions, make connections between children's responses with other children, anticipation and observation, critical speech skill practice, storytelling practice, learning equations and differences, using vocabulary, using language descriptive, thank you, and increase your confidence.

While the benefits of Show and Tell method is best stated by Moffet and Wagner (1976 as cited in Bohning, 1981) stated that some benefits of doing Show and Tell method are to improve communication skill and practice it in front of audience. It also becomes happy time with other mates to share with about something special, talking about their feeling, excited or proud about it. This methods also given opportunity to students to develop their language skill and with careful coaching, it can assist children in enhancing their communication skills and confidence in sharing narratives or speaking to groups (Poveda, 2001 as cited in Mortlock 2014). According to (Patsalides: 2010), this technique has several benefits and advantages as follows.

a. Students learn to speak and listen.

b. Students can learn how to be an audience and introduce themselves.

c. Students can learn to ask questions according to the theme discussed.

d. Students can learn to link responses among the students.

e. Students can learn to anticipate and observe.

f. Students can practice critical reasoning skill.

g. Students learn storytelling.

h. Students learn to use descriptive language.

i. Improving self-confidence.

Based on several benefits of show and tell method, it can be concluded that there is one aspect that can be developed, that is social aspect. Emotional indicators with increased confidence level. It will used as a guide in developing learning steps with show and tell method. Show and Tell, dealing with the learning of speaking, students in this case will show what they bring from home and then they will try to describe the objects to others in the classroom. To make a better speaking, the 
students are able make a good preparation for having good performance in front of their classmates. So in this activity, students are conditioned to be more active. They can ask questions such as where the objects bought from are, when the student get the objects, and so on.

\section{E. Learning Speaking by Show and Tell Method}

There are several steps in running the Show and Tell the method by Revermann and Takdiroatun Musfiroh in Ningsih (2014) describes the steps in applying Show $\&$ Tell method, which are:

a. At certain times, children are asked to bring favorite objects to be shown and told in front of the class.

b. The teacher gives the child a chance to perform and notify objects brought from home when the child will appear the center of attention for his friends.

c. Other children ask questions to children who are appear.

Questions should be pre-determined. While Takdiroatun Musfiroh in Ningsih (2014) also describes the steps of showing and telling the implementation is as follows:

a. Children form a circle on the ground floor (carpets, mats, and the like).

b. Each group consists of 7-10 children.

c. Opening activities with regards. d. Guiding one child to lead a common prayer.

e. Welcome the children one by one by mentioning his name.

f. Giving good words and arousing the interest of children.

g. Give the child a chance to show what will happen used for show and tell.

h. Explain the show and tell method procedures. If necessary, the teacher can give examples of how to do show and tell. This is done for 5 minutes. To apply this method, the teacher gives an example of a real object for children.

So, it can be concluded that Show and Tell is as one method of teaching speaking for children. They asked by teacher to speak up in the front of the class about something that they familiar with and it can be done in group. So, it can improve the ability and the confidence of the student in speaking English.

\section{F. The Importance of Show and Tell Method}

Show and Tell sets the stage for children to become comfortable when speaking in public. When presenting during show and tell, students are expected to talk about a variety of topics, organize their thoughts and convey main ideas. So what better way for students to practice those skills than with Show and Tell? After all, Show and Tell helps students with planning 
their presentation, public speaking, using different types of vocabulary and descriptive language, and fielding questions from their classmates.

In addition, show and tell can be a great tool to help English language learners, giving them a chance to practice academic vocabulary, pronunciation and other basic skills they need to succeed.

The reasons children need Show and Tell in the classroom:

1. The show must go on

In today's competitive school system, sadly many teachers are omitting show and tell from their Kindergarten or primary curriculum, because they view the process as a waste of valuable learning time that could otherwise be spent on reading and writing.

2. The English language art standards for kindergarten

In Kindergarten, the student must learn to speak clearly, guide a listener to understand important ideas, describe people, places, things and locations, increase vocabulary, speak in complete sentences, follow and create a sequence, and paraphrase what they have heard.

3. Meeting the standards

Let's list the possible gains that students can receive from show and tell:

- Learn to speak and listen.
- Learn how to be an audience and introduce themselves.

- Learn how to ask inquiry based questions.

- Learn to make connections between student responses.

- Anticipate and observe.

- Practice critical reasoning skills.

- Practice storytelling.

- Learn same and different.

- Use vocabulary- doll, computer, toy car, puppet.

- Use descriptive language.

- Say thank you.

- Increase confidence.

\section{G. The Advantages and Disadvantages of Show and Tell Method}

\section{The Advantages}

Acording to Ningsih (2014) there are several advantages of the show and tell method. Some are as follows:

a. A very simple method, so easy to apply to children.

b. Using a concrete object, making it easier for a child to tell a story.

c. Allow children to be actively involved because of emphasizing participatory approaches in the learning process. 
Takdiroatun Musfiroh in Ningsih (2014) adds the advantages of show which are:

a. Effectively develops the ability to speak in public (public talking). Ability to speak in public (public speaking) is one of the characteristics of self confidence.

b. Train the child to do problem solving (problem solving), the moment tells the child's learning to collect information related to that object show.

\section{The Disadvantages}

In addition there are advantages of using show and tell method, according to Ari In Ningsih (2014) disadvantages of Show \& Tell Method are:

a. The use of methods should always be done with teacher supervision. Because this method requires guidance if learners difficulty in telling the object used.

b. The use of this method cannot be used in a sudden condition, is due to the need for object preparation and experience will be notified.

c. The time it takes to do it show and tell is limited. This is because show and tell is done regularly to take turns, so all the kids can perform at that moment the provided should be quite a lot.

Show and Tell method is very easy to be implied for children because they can say anything about object that they familiar with, but it needs more time because they should show one by one and the time is limited to applied in classroom.

\section{Conclusion}

Show and Tell method can make the students enjoy the learning process, the students can open their mind to tell about something that they familiar with. The students have good preparation so they can show up their performance in speaking well. If the students always try speaking of course it can improve their ability in speaking English. In using Show and Tell method, there were many advantages as follows:

a. The learning activities more interesting and not makes the students be bored

b. The students easy to understand the words given.

c. The students enjoy the learning process.

In this era, the children should be able to speak English because some reason; the show must go on, the English language art standards for kindergarten, and meeting the standards. Show and Tell, dealing with the learning of speaking, students in this case will show what they bring from home and then they will try to describe the objects to others in the classroom. To make a better 
speaking, the students are able make a good preparation for having good performance in front of their classmates. So in this activity, students are conditioned to be more active.

\section{References}

Bohning, G.1981. Show-and-Tell: Assessing Oral Language, Reading Horizon Journal, 22,15. Available at http://scholarworks.wmich.edu/reading. Retrieved on June 10, 2019.

Dailey, K. 1997. Sharing centers: An alternative approach to show and tell . Early Childhood Education Journal. Vol. 24., No. 4., 223-227. Volume I | Number 1 | February 2016.

Donna E. Norton. 1980 "The Effective Teaching O f Language Arts" . Ohio: A Bell \& Haowell Company.

H. A. R. Tilaar. 2013. Unexpected Show and Tell method. United States: Libraries Unlimited, Inc.

Haley, Hall Marjorie and Theresa Y. Austin. 2004 "Content - Based Second Language Teaching and Learning". New Jersey: Pearson Education, Inc.

Hubbard, Michelle. 2009. Show and Tell. http://www.hubbardscupboard.org/show_and_tell.html. Retrieved on June 10, 2019.

Mortlock, A. 2014. Children's narratives and show-and-tell: What the story books tell us about 'being known,' 'being better,' and 'being judged'? http://www.hekupu.ac.nz/Journal\%20files/Issue5\%20November\%202014/6\%20Anita\% 2. Retrieved on June 10, 2019.

Musfiroh, T. 2005. Bermain sambil belajar dan mengasah kecerdasan (simulasi multiple intelligences anak usia taman kanak-kanak). Jakarta: Departemen Pendidikan Nasional.

Nathwani, Dina. 2012. The Show and Tell Technique.

http://adpu.wordpress.com/2012/02/29/the-show-and-tell-technique/. Retrieved on June $10,2019$.

Ningsih, Okki R. M. 2014. Meningkatkan percaya diri melalui metode Show And Tell pada anak kelompok A Tk Marsudi Putra, Dagaran, Palbapang, Bantul, Yogyakarta.

Patsalides, Laurie. 2010. The Case for Classroom Show and Tell. Ed Byalinah. Retrieved on June 9th, 2019.

Random House Incorporation. 2010. Random House Kernerman Webster's College Dictionary. Tel Aviv: K Dictionaries Ltd

Shepley, Phil. 2010. What is Show And Tell?. Ed Bronwyn Harris. http://www.wisegeek.com/what-is-show-and-tell.htm. Retrieved on June 10, 2019. 
Slamet Suyanto. 2005 Dasar-dasar Pendidikan Anak Usia Dini. Yogyakarta: Hikayat Publishing.

Thornbury, S. 2005. How to Teach Speaking: New York : Pearson.

Walter, E. 2008. Cambridge advanced learner's dictionary (third edition). Cambridge: Cambridge University Press. 